\title{
Answer to H.-J. Rätz's comment on my paper "Criteria for sustainable fisheries on juveniles illustrated for Mediterranean hake: control the juvenile harvest, and safeguard spawning refugia to rebuild population fecundity"
}

\author{
John F. Caddy \\ E-mail: jfcaddy1@yahoo.co.uk
}

\begin{abstract}
Respuesta al comentario de H.-J. Rätz sobre mi artículo "Criterio para una pesca sostenible de juveniles, tomando como ejemplo la merluza del Mediterráneo: control de la pesca de juveniles y preservación de refugios para reproductores, con el fin de rehacer la fecundidad de la población"

Citation/Como citar este artículo: Caddy J.F. 2015. Answer to H.-J. Rätz's comment on my paper "Criteria for sustainable fisheries on juveniles illustrated for Mediterranean hake: control the juvenile harvest, and safeguard spawning refugia to rebuild population fecundity". Sci. Mar. 79(3): 303-304. doi: http://dx.doi.org/10.3989/scimar.04270.09B
\end{abstract}

Editor: J. Lloret.

Received: May 14, 2015. Accepted: May 15, 2015. Published: September 10, 2015.

Copyright: () 2015 CSIC. This is an open-access article distributed under the Creative Commons Attribution-Non Commercial Lisence (by-nc) Spain 3.0.

The main two comments H.J. Rätz made are replied to here (though not necessarily refuted):

"Dynamic ecological effects": While I did not enter into a specific discussion of hake ecology, I showed that I have been concerned with environmental issues. For example, trophic questions are touched on briefly, including the error introduced into food web studies by ignoring high juvenile natural mortality rates. An ecological model should be expressed in a size-based form with a reciprocal $\mathrm{M}$ formulation or alternative since, as I indicated (numerically if not ponderally), larvae and juveniles surely make up the major share of predated fish. I also feel that the refugium approach is ecologically-motivated, since here we are not just talking about conserving spawners, but also conserving the epifauna that concentrates demersal fish in refugia on the shelf edge or elsewhere.

The other issue raised by Hans-Joachim was on MSY: first, as I say in the paper, it must be questioned whether MSY derived from a fishery on juveniles (where both $\mathrm{F}_{\mathrm{t}}$ and $\mathrm{M}_{\mathrm{t}}$ are high), is comparable with the usual form of MSY employed in adult fish stock assessments? The conclusion I quoted on past assess- ments of hake, which stated that fishing mortality had reached $9 \mathrm{~F}_{\mathrm{MSY}}$, found me comparing this with the Schaefer model, where such a conclusion would seem geometrically improbable. Also, if $\mathrm{F}_{\mathrm{MSY}}$ is equated with an $\mathrm{F}_{0.1}$ calculated using constant $\mathrm{M}$, it would not be surprising if the $\mathrm{F}_{\mathrm{MSY}}$ is so low.

I have added a reference to Beverton's last paper (1993) written at the time when he came to FAO to prepare a review on natural mortality rates (which was never completed). As I see it, his most recent review of how B $+\mathrm{H}$ 's important text has been used in assessments anticipated some of my ideas in the present paper. He actually made a contribution to my work on the reciprocal M model. At first he was reluctant about the reciprocal model, since he had little experience on fisheries for juveniles, but he had no serious questions on it. Certainly, his last paper seems to me to suggest that we should be investigating more carefully issues on the earlier life history stages, which have been a priority of mine.

On this subject, I have to add that earlier on I had trouble from referees who insisted I apply a spawnerrecruit relationship (SRR). I am not convinced by those 
who think that SRRs provide adequate evidence for specific mechanisms operating in the first 2 or 3 years of the life history between spawning and recruitment, and no data were available to apply this option in the hake paper. It must be considered that an SRR is constructed from a series of annual age compositions of (say) a minimum of a decade in duration, but involves no obligatory field work on early life history stages when critical events can occur. In the current situation, when climate change is apparently underway, an SRR is not a particularly accurate way of predicting future recruitment levels. I would go as far as to say that one origin of its popularity is the "constant M hypothesis", which leaves stock assessment workers no choice but to use an SRR, since there has been no other way of modeling mortalities in the early life history.
I am conscious that a return to the despised method of fecundity-per-recruit calculation is not an ideal approach either, and monitoring pre-recruit abundance annually by larval surveys and fine-mesh post-larval surveys could be the way to go if funds were available. An obvious criticism of the present paper is the use of data from another species to estimate larval survival. A systematic study of larval survival rates could be a useful contribution, however. One of the issues I have been writing about recently is the neglected area of quantifying pre-recruit and recruit habitat. I would suggest that a pro-active approach to protecting/enhancing these once identified would be more than useful (though less relevant perhaps for European hake?). 